\title{
Kan tvillingabort forsvares etisk?
}

Vi har sterke moralske intuisjoner mot å ta liv, og dette gjelder også i situasjoner hvor man skal ta livet av det ene fosteret og la det andre leve, skriver professor Per Nortvedt.

\section{Per Nortvedt}

Professor emeritus

Senter for medisinsk etikk, Universitetet i Oslo

Sykepleien 2019107 (76319) (e-76319)

DOI: 10.4220/Sykepleiens.2019.76319

Et forslag om endring i abortloven er for tiden ute på høring. Regjeringen foreslår nemndbehandling av såkalte fosterreduksjon eller tvillingabort.

Jeg velger å bruke betegnelsen «tvillingabort», selv om det kan være snakk om flerlinger, og selv om man bare aborterer den ene av tvillingene. Begrepet «fosterreduksjon» er etter mitt syn unødig instrumentelt og teknisk, og dermed dehumaniserende.

Slike aborter har vært utført ved St. Olavs hospital i Trondheim. Etter at Helsedepartementet i 2016 slo fast at tvillingabort av friske fostre er tillatt, er det utført 25 slike aborter. 
Saken har vakt stor oppmerksomhet og debatt, fordi regjeringen har snudd i spørsmålet. Det

kontroversielle i denne snuoperasjon reflekteres ikke minst i årets mobilisering til kvinnedagen 8. mars, der retten til selvbestemt tvillingabort ble en av hovedparolene.

\section{Du kan bestemme selv før tolvte uke}

I 2016 valgte regjeringen å legge departementets tolkning av abortloven til grunn. Konklusjonen var at abort på ett eller flere foster i et flerlingsvangerskap var dekket av selvbestemmelsesparagrafen $\mathrm{i}$ nåværende lov. Norge ble med det et av få land i Europa som kom til denne konklusjonen. For å vri litt på stortingsrepresentant Kjell Ingolf Ropstads (KrF) utsagn på Debatten i NRK i februar: Kan man abortere et barn $i$ et «enlingsvangerskap», kan man gjøre det samme i et flerlingsvangerskap.

Jussen ser ingen forskjell på kvinnens rett til selvbestemmelse i et ordinært enlingsvangerskap og $i$ et tvilling- eller flerlingsvangerskap før tolvte uke.

\section{«Abort er et uløselig moralsk dilemma der man søker å finne en balanse mellom rett til liv for den ene parten og rett til autonomi for den andre.»}

Per Nortvedt

\section{Moralske forskjeller}

Spørsmålet er imidlertid om abort på et av to eller flere barn i det samme svangerskapet etisk sett er sammenliknbart med avbrytelse av et enlingsvangerskap før tolvte uke.

Jeg vil argumentere for at det er moralsk relevante forskjeller mellom disse to formene for abort. Derfor er jeg er enig i regjeringens nye forslag som krever nemndbehandling av tvillingaborter. Av medisinske grunner må slike aborter foretas etter uke tolv, men beslutningen kan tas før uke tolv fra kvinnenes side. 
I et innlegg i Dagens Medisin skriver Reidar Pedersen følgende: «Begrunnelsen for å bringe inn en nemnd er - i tillegg til at fosteret tilkjennes et økende vern - at risikoen for komplikasjoner ved abortinngrepet da er $\varnothing \mathrm{kt}$ og at medisinske vurderinger kommer sterkere inn i bildet. Dette siste er også tilfellet ved selektiv abort ved flerlingsvangerskap.» (1)

\section{Det er flere argumenter for nemndbehandling}

Jeg mener disse argumentene taler for nemndbehandling:

Tvillingabort er å regne som selektivt svangerskapsavbrudd og kan derved vanskelig falle inn under lovbestemmelsen om selvbestemt abort. Man $\varnothing n s k e r$ barn, men det er antall barn som ikke er akseptabelt å bringe frem, ikke selve det å fullføre svangerskapet.

Abort er i utgangspunktet etisk utfordrende og problematisk, og det må være særlig gode grunner til å $\varnothing$ nske svangerskapet fullbyrdet med bare det ene fosteret.

Et annet argument er at det er en risiko for komplikasjoner for det andre barnet ved å abortere det ene. Risikoen varierer fra 6-10 prosent.

Man må også ta hensyn til at tvillinger har relasjoner under svangerskapet og gjennom hele livet. Å frarøve et menneske en bror eller søster man potensielt er så knyttet til, skal det gode grunner til å gjøre.

\section{To premisser for argumentene}

Argumentet om kvinnens rett til selvbestemmelse kan ikke være en absolutt rett. I og med at det er en annen part som er berørt, det ufødte barnet, må alltid kvinnens og familien rett til selvbestemmelse og derved familieplanlegging balanseres mot det ufødte barnets rett til å leve. 
Nåværende abortlov er en pragmatisk løsning på dilemmaet mellom selvbestemmelse for kvinnen og rett til liv for barnet. Loven av 1978 tar hensyn til at fosteret har en gradvis $\varnothing$ kende moralsk status og derved anerkjent menneskeverd gjennom svangerskapet, helt opp til barnet ansees å være levedyktig, da det tilkjennes fulle rettigheter og abort ikke lenger er tillatt. Det er veldig få som mener at man har rett til å avbryte et svangerskap på et levedyktig foster, selv om noen også har prøvd å forsvare en slik rett (2).

\section{Moralske intuisjoner}

Abort er et uløselig moralsk dilemma der man søker å finne en balanse mellom rett til liv for den ene parten og rett til autonomi for den andre. Vi har sterke moralske intuisjoner mot å ta liv, og dette gjelder også i situasjoner hvor man skal ta livet av det ene fosteret og la det andre leve. Særlig gjelder dette tvillinger som også biologisk er så nært knyttet til hverandre, i fosterstadiet og vanligvis gjennom hele livet. Jeg kan vanskelig tenke meg at den gjenlevende tvilling ikke en eller annen gang blir kjent med at han eller hun kunne ha hatt en bror eller søster som ble abortert bort. Hvordan ville en slik kunnskap virke på den gjenlevende bror eller søster?

Ingen av argumentene i denne debatten er uttømmende eller fullstendig overbevisende. Likevel mener jeg at argumentene for å innskrenke retten til tvillingaborter er i tråd med sterke moralske intuisjoner om særlig sårbare individers rett til beskyttelse ved at visse moderate hindringer settes ved den gravides rett til selvbestemmelse.

Til informasjon: Forfatteren er selv enegget tvilling og har personlig kjennskap til noere bånd mellom tvillinger.

\section{Referanser}

1. Pedersen R. Om fosterreduksjon. Dagens medisin, 2 november. Tilgjengelig fra:

https:/www.dagensmedisin.no/artikler/2014/O2/11/omfosterreduksjon/ (nedlastet 30.03.2019). 
2. Giubilini A, Minerva F. After-birth abortion: Why should the baby live? Journal of Medical Ethics

2011;39(5):261-63. 